\title{
Early Visean bryozoans from the Shishtu II Member, Shishtu Formation, central Iran
}

\author{
Zoya Tolokonnikova $^{1} \&$ Mohsen Yazdi-Moghadam² \\ ${ }^{1}$ Kuban State University, 353235, Aphipskij, post box 30, Russia; e-mail: zalatoi@yandex.ru \\ ${ }^{2}$ NIOC Exploration Directorate, Seoul Str., 1994814695, Tehran, Iran; e-mail: mohsen.moghadam@gmail.com
}

\begin{abstract}
Four bryozoan species are described from the upper member (Shishtu II) (Visean, Early Carboniferous=Mississippian) of the Shishtu Formation of central Iran: Nikiforovella ulbensis Nekhoroshev, 1956, Nicklesopora elegantulaformis (Nekhoroshev, 1956), Primorella cf. iranica Gorjunova, 2006, and Nikiforopora intermedia (Nikiforova, 1950). This Visean assemblage shows close palaeogeographical affinities of Iran with Kazakhstan and Russia (eastern Transbaikalia, Kurgan region).
\end{abstract}

Key words: Bryozoa, Visean, Iran

\section{Introduction}

Bryozoans are widespread in Carboniferous deposits of most regions worldwide (Ross, 1981; Gorjunova et al., 2004). The systematic composition of bryozoan faunas some areas is unknown or poorly known, however, even though numerous fragments of colonies may be present. Iran is one such region: only three endemic species have been described previously from the Lower Carboniferous: Primorella iranica, Heloclema magnificum, and Worthenopora elbursensis (Gorjunova, 2006). The present contribution aims to characterise the bryozoans from the Visean Shishtu 2 Member of the Shishtu Formation of central Iran. In addition, the regional diversity of this fossil group is evaluated and the palaeobiogeographical affinities in the study area are discussed.

\section{Geological setting}

The Shishtu Formation was first described by Stöcklin et al. (1965) from the Shotori Mountains. It comprises a succession of several hundreds of metres of dark fossiliferous limestones and shales; these are transitional between the underlying Bahram Formation and the overlying Sardar Formation (Wendt et al., 1997). The Shishtu Formation is divided into two members: the lower Shishtu I and the upper Shishtu II Members. The age of the Shishtu I Member is considered to be Frasnian-Famennian (Weddige, 1984; Yazdi, 1999), whereas the Shishtu II Member is attributed to the Tournaisian to Early Visean (Stöcklin, 1972). The bryozoan fauna described here was recovered from an outcrop at Howz-e-Dorah (Fig. 1). This is located at the southern end of the Shotori Range. The lime- 


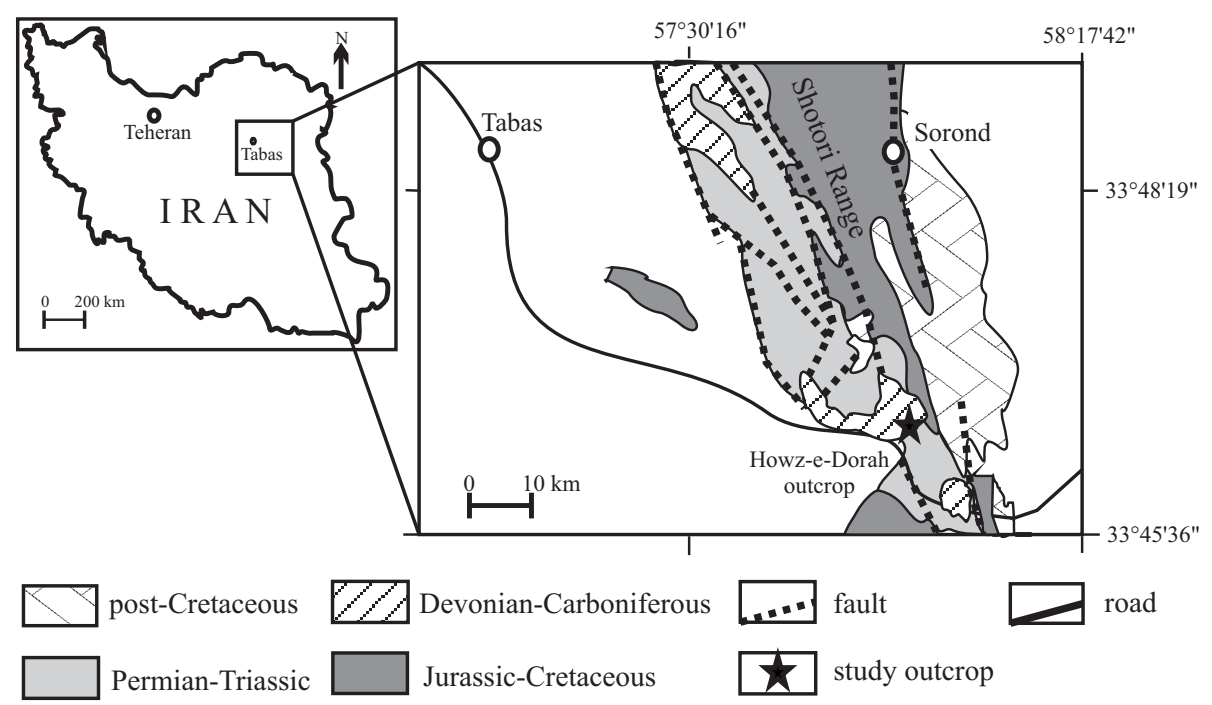

Fig. 1. Geological map and location of the Howz-eDorah outcrop.

stones of the Shishtu II Member contain abundant fossils: bryozoans, crinoids, brachiopods, foraminifers, ostracods, and radiolarians (Fig. 2). The age of the bryozoan-bearing beds is estimated as Early Visean.

According to Wendt et al. $(1997,2005)$ and Golonka (2007) the Palaeozoic sediments in northern Iran represent a fragment of Laurussia (Turan Plate). Amalgamation of the Iranian (northern Gondwana) and Turan (southern part of Eurasia) plates occurred during the Mesozoic as a consequence of closure of the Palaeothetys Ocean due to subduction (Golonka, 2002). During the Early Carboniferous the study area represented an isolated carbonate microplate (Wendt et al., 2005).

\section{Material and method}

The material for the present study was collected from the Shishtu II Member. The bryozoans were investigated in 20 thin sections using a binocular microscope. The abundant fragments of the bryozoan colonies represent well-known Palaeozoic orders viz the Cystoporata, Trepostomata, Cryptostomata (suborder Rhabdomesina) and Fenestrata. In the available material three rhabdomesines were identifiable at species level: Nikiforovella ulbensis Nekhoroshev, 1956, Nicklesopora elegantulaformis (Nekhoroshev, 1956) and Primorella cf. iranica Gorjunova, 2006. The trepostome bryozoan Nikiforopora imtermedia (Nikiforova, 1950) was

Fig. 2. Stratigraphical column of the Shishtu 2 Member of the Shishtu Formation. 
also found. Remains of fenestellid bryozoans are abundant, but their identification at species level is difficult because of fragmentation and the absence of good sections. Fenestellids are represented by Fenestella sp., Spinofenestella sp., Minilya sp. and Arborocladia sp. Cystoporates identified only at generic level include Fistulipora sp., Cyclotrypa sp. And Fistulamina sp. Also present are the trepostome Lieoclema sp. and the rhabdomesines Rhombopora sp., Primorella sp. and Nikiforovella sp.

The systematic descriptions of the bryozoan fauna are based on measurements of the morphological characteristics, which are specific for each order. Statistical values (mean, standard deviation, variation coefficient, and minimum/maximum values) were calculated according to Köhler et al. (1996). Principal coordinates analysis was carried out applying the Jaccard index to demonstrate similarities between the bryozoan faunas of Iran and some other regions during the Visean (95\% concentration ellipses, PAST program; Jaccard, 1901; Hammer et al. 2001). This multivariate ordering technique allowed the data to be projected onto two dimensions, in order to visualise trends and groupings.

The studied material is stored in the Palaeontology Department of the National Iranian Oil Company Exploration Directorate.

\section{Systematic palaeontology}

Phylum Bryozoa Ehrenberg, 1831

Class Stenolaemata Borg, 1926

\subsection{Order Trepostomata Ulrich, 1882}

\section{Suborder Amplexoporina Astrova, 1965}

\subsubsection{Family Stenoporidae Waagen \& Wentzel, 1886}

\subsubsection{Genus Nikiforopora Dunaeva, 1964}

Type species: Batostomella concentrica Nikiforova, 1927, Lower Carboniferous, Ukraine.

Diagnosis: Branched colonies with narrow exozone. Autozooecia with oval apertures. Diaphragms rare, incomplete or centrally perforated; better developed in exozones. Exilazooecia rare. Acanthostyles large, rare. Tubules abundant several locations. Autozooecial walls thin in endozone; strongly and regularly thickened in exozone.

Occurrence: Eurasia; Late Devonian to Late Carboniferous.

Discussion: Nikiforopora Dunaeva, 1964 differs from Tabulipora Young, 1883 by the presence of rare diaphragms and regularly thickened walls, and from Rhombotrypella Nikiforova, 1933 by the irregularly polygonal sectional shapes of the autozooecia in the endozones.

\subsection{Nikiforopora intermedia (Nikiforova, 1950) \\ 1950 Tabulipora? intermedia, Nikiforova, pp. 103-104, pl. 6, fig. 6-6c. \\ (For specimens under study see Figure 3 A-D; Table 1) \\ Material: MZY 3568 (two colonies), MZY 3566 (three colonies). \\ Description: Dichotomously branched colonies. Exozone narrow that endozone. Autozooecial}

Table 1. Descriptive statistics for Nikiforopora intermedia (Nikiforova, 1950).

Abbreviations: $\mathrm{n}=$ number of measurements; $\mathrm{X}=$ mean; $\mathrm{sd}=$ standard deviation; $\mathrm{cv}=$ coefficient of variation; $\min =$ minimal value; $\max =$ maximal value .

\begin{tabular}{lcccccc}
\hline \multicolumn{1}{c}{ Nikiforopora intermedia (Nikiforova, 1950) } & $\mathbf{n}$ & $\mathbf{x}$ & $\mathbf{s d}$ & $\mathbf{c v}$ & $\min$ & $\max$ \\
\hline branch diameter [mm] & 5 & 1.000 & 0.152 & 15.24 & 1.000 & 1.370 \\
exozone width [mm] & 5 & 0.028 & 0.027 & 9.780 & 0.250 & 0.300 \\
endozone width [mm] & 10 & 0.372 & 0.051 & 13.75 & 0.320 & 0.500 \\
aperture length [mm] & 10 & 0.194 & 0.040 & 20.64 & 0.120 & 0.250 \\
aperture width [mm] & 10 & 0.104 & 0.022 & 21.23 & 0.075 & 0.150 \\
exilazooecia width [mm] & 10 & 0.067 & 0.012 & 17.89 & 0.050 & 0.075 \\
number of acanthostyles between apertures & 10 & 7.300 & 1.760 & 24.20 & 5.000 & 10.00 \\
exozonal wall thickness [mm] & 10 & 0.085 & 0.017 & 20.56 & 0.050 & 0.100 \\
\hline
\end{tabular}



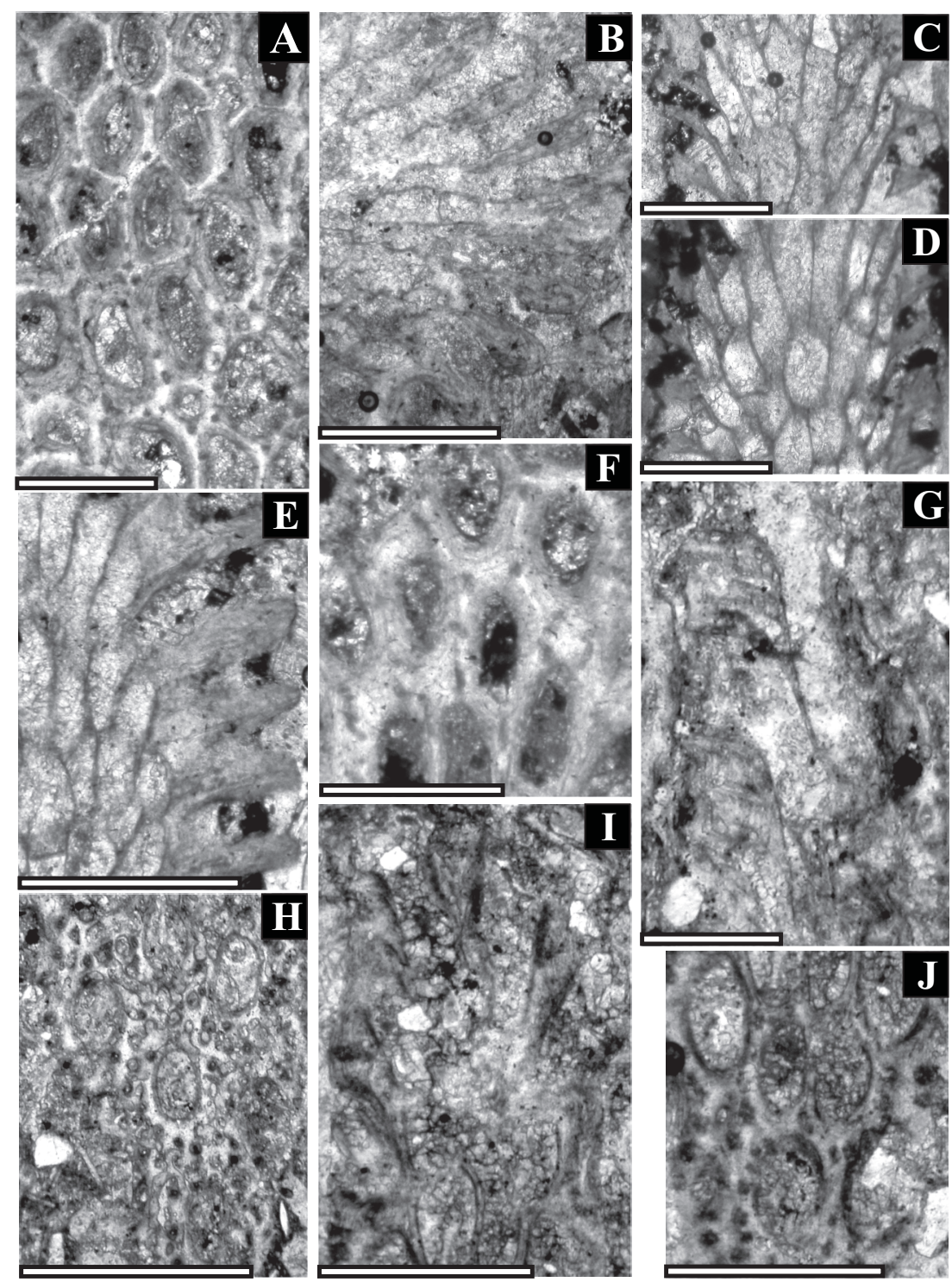

Fig. 3. Bryozoans from the Shishtu 2 Member.

A-C: Nikiforopora intermedia (Nikiforova, 1950); A: MZY 3568, tangential section, scale bar $=0.5$ mm; B: MZY 3568, transverse section, scale bar $=0.5 \mathrm{~mm} ; \mathrm{C}: \mathrm{MZY}$ 3566b, longitudinal section, scale bar $=0.5$ mm; D: MZY 3566b, longitudinal section, scale bar $=0.5$ $\mathrm{mm}$.

E-F: Nicklesopora elegantulaformis (Nekhoroshev, 1956); E: MZY 3568, longitudinal section, scale bar $=0.5 \mathrm{~mm}$; F: MZY 3568, tangential section, scale bar $=0.5$ $\mathrm{mm}$.

G-H: Nikiforovella ulbensis Nekhoroshev, 1956; G: MZY 2049, longitudinal section, scale bar $=$ 0.2 mm; H: MZY 2049, tangential section, scale bar $=0.5 \mathrm{~mm}$.

I-J: Primorella cf. iranica Gorjunova, 2006; I: MZY 2054, longitudinal section, scale bar $=0.5 \mathrm{~mm}$; J: MZY 2054, tangential section, scale bar $=0.5 \mathrm{~mm}$.

diaphragms incomplete, hook-like. Single diaphragms located in exozone. Autozooecial walls $0.014-0.32 \mathrm{~mm}$ thick in endozones, regularly thickened in exozones. Autozooecia with long-oval or elongated polygonal apertures located in low areas on the surface colony. Some apertures covered with a terminal diaphragm at the surface. Exilazooecia short, rounded in cross-section, rare. Acanthostyles uniformly located in a single row around apertures, 0.025 $\mathrm{mm}$ in diameter. Tubules abundant, $0.014 \mathrm{~mm}$ in diameter.

Occurrence: Kazakhstan: Lower Visean (Mississippian, Lower Carboniferous).

Discussion: Nikiforopora intermedia (Nikiforova, 1950) differs from $N$. rotaji (Trizna, 1958) from the Visean of the Kuznetsk Basin by the presence of single diaphragms in the autozooecia (vs. 6 diaphragms in $N$. rotaji), and in the smaller size of the acanthostyles $(0.025 \mathrm{~mm}$ vs. $0.10-0.15 \mathrm{~mm}$ in N.rotaji).

\subsection{Order Cryptostomata Vine, 1884}

Suborder Rhabdomesina Astrova \& Morozova, 1956

\subsubsection{Family Nicklesoporidae Goryunova, 1985}

4.2.1.1. Genus Nicklesopora Bassler, 1952

Type species: Rhombopora elegantula Ulrich, 1884, Lower Carboniferous, United States of America. 
Diagnosis: Branched colonies. Axial region of branches formed by a few axial zooecia, not in distinct bundles. Autozooecia initially polygonal, irregular in transverse section becoming hexagonal. Autozooecial apertures oval, arranged in regular alternating longitudinal rows. Single short, commonly massive superior hemiseptum near zooecial bend; thin short inferior hemiseptum sometimes present. Diaphragms rare. Paurostyles common, most in a single series enclosing apertures in polygonal patterns. Monticules rare, consisting of one much enlarged polymorph, surrounded by smaller polymorphs.

Occurrence: Eurasia, North America; Devonian-Permian.

Discussion: Nicklesopora Bassler, 1952 differs from Rhabdomeson Young \& Young, 1874 by the development of several axial zooecia instead of one and in the presence of only paurostyles instead of acanthostyles and paurostyles as in Rhabdomeson. Nicklesopora differs from Orthopora Hall, 1886 by possessing axial zooecia and lacking acanthostyles.

\subsection{Nicklesopora elegantulaformis}

(Nekhoroshev, 1956)

(For specimens under study see Figure 3 E-F; Table 2)

1956 Rhombopora elegantulaformis, Nekhoroshev, pp. 256-258, pl. 49, figs. 3-4b.

Material: Single specimen MZY 3568.

Description: Colony branched, branches 1.6 $\mathrm{mm}$ in diameter. Endozones $0.4 \mathrm{~mm}$ wide, exozones $0.55 \mathrm{~mm}$ wide. Autozooecial walls $0.014 \mathrm{~mm}$ thick in endozones, $0.10-0.12 \mathrm{~mm}$ thick in exozones. Hemisepta not observed. Diaphragms rare. Autozooecial apertures oval, arranged in regular rhombic pattern on colony surface, spaced 5 per $2 \mathrm{~mm}$ along branch and 6-7 per $2 \mathrm{~mm}$ across branch. Distance between aperture centres $0.40-0.47 \mathrm{~mm}$ along branch and $0.20-0.24 \mathrm{~mm}$ across branch. Abundant paurostyles arranged in single row between autozooecial apertures, forming a regular rhombic to hexagonal pattern around apertures, $0.014-0.025 \mathrm{~mm}$ in diameter. Low ridges present between apertures.

Occurrence: Kazakhstan: Djaltursk suite, Late Visean; Kokpektinsk suite, Early Serpukhovian (Mississippian, Lower Carboniferous).

Discussion: Nicklesopora elegantulaformis (Nekhoroshev, 1956) from the Early Carboniferous to Kazakhstan is similar to N. elegantula (U1rich, 1884) from the Keokuk (Visean), Lower Carboniferous of the USA, but differs in the number of autozooecial apertures in $2 \mathrm{~mm}$ (5 vs. 3.6 per $2 \mathrm{~mm}$ along the branch, and $6-7$ vs. 4.8 per $2 \mathrm{~mm}$ across the branch in N. elegantula).

\subsubsection{Family Nikiforovellidae Gorjunova 1975}

\subsubsection{Genus Nikiforovella Nekhoroshev, 1948}

Type species: Nikiforovella alternata Nekhoroshev, 1948, Lower Carboniferous, Altai, Russia. Diagnosis: Branched colonies. Autozooecia diverging at low angles from distinct median axis. Hemisepta absent, diaphragms rare. Autozooecial walls laminated, with dark zooecial boundaries. Metazooecia few between longitudinally successive autozooecial apertures; acanthostyles common to abundant. Longitudinal ridges absent.

Occurrence: Worldwide; Devonian to Permian. Discussion: Nikiforovella Nekhoroshev, 1948 is largely similar to Streblotrypella Nikiforova, 1948 , but differs mainly in the shape of the autozooecia, which bend at higher angles in the exozone, and by the absence of longitudinal ridges. Moreover, styles can be absent in Streblotrypella.

Table 2. Descriptive statistics for Nicklesopora elegantulaformis (Nekhoroshev, 1956) (for abbreviations, see Table 1).

\begin{tabular}{lrrrrrr}
\hline Nicklesopora elegantulaformis (Nekhoroshev, 1956) & $\mathbf{n}$ & $\mathbf{x}$ & sd & cv & $\min$ & $\max$ \\
\hline aperture length [mm] & 7 & 0.167 & 0.023 & 14.12 & 0.150 & 0.200 \\
aperture width [mm] & 7 & 0.095 & 0.020 & 21.48 & 0.075 & 0.120 \\
exozonal wall thickness [mm] & 5 & 0.112 & 0.010 & 9.78 & 0.100 & 0.120 \\
paurostyle diameter [mm] & 10 & 0.017 & 0.005 & 29.26 & 0.014 & 0.025 \\
\hline
\end{tabular}




\subsection{Nikiforovella ulbensis Nekhoroshev,} 1956

(For specimens under study see Figure $3 \mathrm{G}-\mathrm{H}$; Table 3)

1956 Nikiforovella ulbensis, Nekhoroshev, pp. 264-266, pl. 51, fig. 3a-d.

Material: Single specimen MZY 2049.

Description: Colony branched, branches 0.75 $\mathrm{mm}$ in diameter. Exozones $0.3 \mathrm{~mm}$ wide, endozones $0.15-0.2 \mathrm{~mm}$ wide. Autozooecial apertures oval, arranged in regular diagonal rows on branch. Autozooecial walls $0.014 \mathrm{~mm}$ thick in endozone, $0.17 \mathrm{~mm}$ thick in exozone. Metazooecia originating at the base of exozone, 1-2 rows between autozooecial apertures; $0.05 \mathrm{~mm}$ in width. Acanthostyles small $0.025 \mathrm{~mm}$ in diameter. Acanthostyles surrounding autozooecial apertures, numbering 5-8.

Occurrence: Kazakhstan: Ul'ba suite, Early Visean (Mississippian, Early Carboniferous); Russia: Transbaikalia, Kulinda horizon, Early Visean (Mississippian, Early Carboniferous).

Discussion: Nikiforovella ulbensis Nekhoroshev, 1956 from the Lower Carboniferous of Kazakhstan is similar to N. mukhini (Nikiforova, 1933) from the Tournaisian-Visean (Early Carboniferous) of Turkmenistan, but differs in thesize of the apertures (0.1-0.12x0.17-0.2 mm vs. 0.06-0.07x0.15-0.17 $\mathrm{mm}$ in N. mukhini), and abundance of acanthostyles.

\subsubsection{Family Rhomboporidae Simpson, 1895}

\subsubsection{Genus Primorella Romantchuk $\mathcal{E}$}

\section{Kiseleva, 1968}

Type species: Primorella polita Romantchuk \& Kiseleva, 1968, Late Permian, Primorje, East Russia.

Diagnosis: Branched colonies with long and tube-like autozooecia budding in spiral order. Oval apertures arranged in regular diagonal rows. Abundant stellatopores in the walls of the exozone.

Occurrence: Eurasia; Carboniferous to Permian.

Discussion: Primorella Romantchuk \& Kiseleva, 1968 differs from other genera of the family Rhomboporidae by the presence of stellatopores, and from Pamirella Gorjunova, 1975 by the absence of acanthostyles.

\subsection{Primorella cf. iranica Gorjunova, 2006}

(For specimens under study see Figure $3 \mathrm{I}-\mathrm{J}$ )

2006 Primorella iranica, Gorjunova, p. 49, pl. 2, fig. 3a-b.

Material: Single specimen MZY 2054.

Description: Branched colony, branches 0.75 $\mathrm{mm}$ in diameter. Exozone $0.17 \mathrm{~mm}$ wide. Autozooecial walls $0.025 \mathrm{~mm}$ thick in endozone, 0.05-0.075 mm thick in exozone. Autozooicial apertures oval, arranged in regular diagonal rows on branch surface $0.15 \times 0.2-0.25 \mathrm{~mm}$. Aperture spacing $0.075 \times 0.1 \mathrm{~mm}$. Stellatopores abundant, 9-11 arranged in a single row around each aperture. Stellatopores $0.025 \mathrm{~mm}$ in diameter.

Occurrence: Iran: Visean (Lower Carboniferous).

Discussion: Primorella iranica Gorjunova, 2006 from the Visean of Iran is similar to the present material. However, the present material is too fragmentary for a complete comparison.

\section{Palaeogeographical relationships of Iranian Visean bryozoans}

Six species of bryozoans are known from the Mississippian (Lower Carboniferous) of Iran: Nikiforovella ulbensis Nekhoroshev, 1956, Nicklesopora elegantulaformis (Nekhoroshev, 1956),

Table 3. Descriptive statistics for Nikiforovella ulbensis Nekhoroshev, 1956 (for abbreviations, see Table 1).

\begin{tabular}{lcccccc}
\hline \multicolumn{1}{c}{ Nikiforovella ulbensis Nekhoroshev, $\mathbf{1 9 5 6}$} & $\mathbf{n}$ & $\mathbf{x}$ & sd & cv & $\min$ & $\max$ \\
\hline aperture length $[\mathrm{mm}]$ & 7 & 0.185 & 0.015 & 8.14 & 0.17 & 0.20 \\
aperture width $[\mathrm{mm}]$ & 7 & 0.111 & 0.010 & 9.59 & 0.10 & 0.12 \\
aperture spacing along branch $[\mathrm{mm}]$ & 7 & 0.284 & 0.020 & 7.28 & 0.25 & 0.30 \\
aperture spacing across branch $[\mathrm{mm}]$ & 7 & 0.228 & 0.026 & 11.69 & 0.20 & 0.25 \\
number of acanthostyles between apertures & 7 & 6.570 & 1.272 & 19.36 & 5.00 & 8.00 \\
\hline
\end{tabular}


and Nikiforopora intermedia (Nikiforova, 1950) were discovered in the Shishtu Formation (Shishtu II Member) of central Iran; Heloclema magnificum Gorjunova, 2006 and Worthenopora elbursensis Gorjunova, 2006 were recorded from Visean rocks of the Eastern Elbrus in the north of Iran (Gorjunova, 2006), and Primorella iranica Gorjunova, 2006 was identified at both localities. Nikiforovella ulbensis Nekhoroshev, 1956 occurs in deposits of the Late Tournaisian from the Kurgan Region (south-western part of Western Siberia, Russia), the Ul'ba suite of the Early Visean of the Rudny Altai (northern Kazakhstan), the Kulinda horizon of the Early Visean of eastern Transbaikalia (Russia), and the Serpukhovian of PriKolyma (northeastern Russia) (Nekhoroshev, 1956; Morozova, 1981; Popeko, 2000; Tolokonnikova, 2012). Nicklesopora elegantulaformis (Nekhoroshev, 1956) is known from the Djaltursk suite (Late Visean) and the Kokpektinsk suite of the Early Carboniferous of the Rudny Altai (Kazakhstan) (Nekhoroshev, 1956). Nikiforopora intermedia (Nikiforova, 1950) was described from the Lower Visean of southern Kazakhstan (Nikiforova, 1950).

Fifteen bryozoans genera are known from the Visean of Iran. The majority of these are cosmopolitan. They represent the following bryozoan orders: Cystoporata - Cyclotrypa, Fistulamina and Fistulipora; Trepostomata -Leioclema and Nikiforopora; Cryptostomata - Rhombopora, Primorella, Nicklesopora, Heloclema and Nikiforovella (all suborder Rhabdomesina), Worthenopora (suborder Ptilodictyina); and Fenestrata - Fenestella, Spinofenestella, Minilya and Arborocladia. Fenestella and Fistulipora had a very widespread distribution during the Visean. They are known from the Lower Carboniferous of all modern continents (Fig. 4). Significant wide distributions are characteristic for Nikiforovella, Rhombopora, Nicklesopora, Fistulamina, Minilya, Nikiforopora and Leioclema (8-11 areas within the boundaries of Eurasia, Australia, and North America). Heloclema, Arborocladia and Cyclotrypa are common in the Visean deposits of the study region and in the middle Urals, Mongolia and Afghanistan, respectively. The other genera are described from Visean deposits of Eurasia and/or North

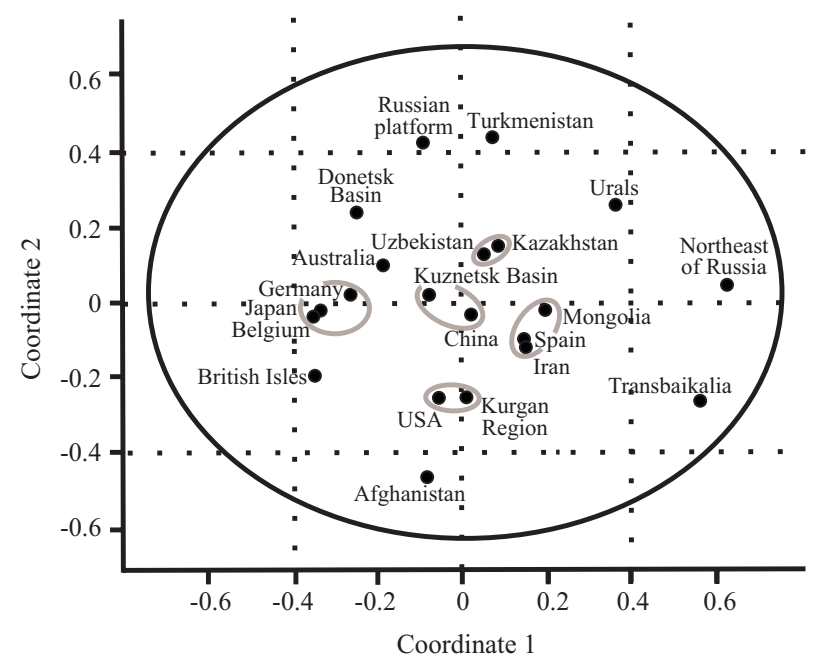

Fig. 4. Principal coordinates analysis showing similarities at generic level between bryozoan faunas of Iran and selected areas during the Visean.

America (3-5 regions). Figure 4 shows the similarity at generic level of the bryozoan assemblages of Iran and some other regions during the Visean. This figure is based on published data from various sources (Schulga-Nesterenko, 1951; Sakagami, 1962; Termier \& Termier, 1971; Xia, 1986; Wyse Jackson 1996, 2006; Ernst, 2005; Wyse Jackson et al., 2006; Tolokonnikova, 2012; Ernst \& Rodriguez, in press), which data were processed by Principal Coordinates Analysis (PCA). PCA shows clustering of Iran, Spain and Mongolia during the Visean. The following regions formed also groups: the Kuznetsk Basin and China; Uzbekistan and Kazakhstan; Belgium, Japan and Germany; the U.S.A. and the Kurgan region. Transbaikalia, north-eastern Russia, Afghanistan, the Russian Platform, the British Isles and Turkmenistan are each isolated from the rest.

\section{Conclusions}

- The Visean bryozoans from Iran include 15 genera with six identified species.

- The studied species assemblage shows palaeogeographical affinities of Iran with Kazakhstan and Russia (eastern Transbaikalia, Kurgan region) during the Visean;

- Cosmopolitan bryozoan genera are reported from the Visean of Iran and some regions of Eurasia, North America, and Australia; 
- Connections between Iran and some regions of Laurussia during the Early Carboniferous (shelf of Kazakhstan and Siberian terrains) are made clear.

\section{Acknowledgements}

Dr. Dmitry Ruban (Southern Federal University, Russia) is thanked for helpful comments. The authors acknowledge authorities of the NIOC Exploration Directorate for permission to publish this work.

\section{References}

Astrova, G.G., 1965. Morphologiya, istoriya razvitiya i sistema ordovikskich i siluriiskikh mshanok [Morphology, history of development and system of the Ordovician and Silurian Bryozoa]. Trudy Paleontologicheskogo Instituta Akademii Nauk SSSR 106, 1-432.

Astrova, G.G. \& Morozova, I.P., 1956. Sistematika mshanok otryada Cryptostomata [Systematics of the order Cryptostomata]. Doklady Akademii Nauk SSSR 110, 661-664.

Bassler, R.S., 1952. Taxonomic notes on genera of fossil and Recent Bryozoa. Journal of the Washington Academy of Sciences 42, 381-385.

Borg, F., 1926. Studies of recent cyclostomatous Bryozoa. Zoologiska Bidrag fran Uppsala 10, 181-507.

Dunaeva, N.N., 1964. Novye mshanki otryada Trepostomata iz nizhnego carbona Donetskogo basseina [New bryozoans from the Order Trepostomata from the Lower Carboniferous of the Donetsk Basin]. Paleontologicheskij Zhurnal 2, 39-44.

Ehrenberg, C.G., 1831. Animalia invertebrata exclusis insects. Symbolae physicae, seu icones et descriptiones corporum naturalium novorum aut minus cognitorum. Pars Zoologica. Vol. 4. Mittler, Berlin, 831 pp.

Ernst, A., 2005. Lower Carboniferous Bryozoa from some localities in Sauerland, Germany. [In:] G.I. Moyano, J.M. Cancino \& P.N. Wyse Jackson (Eds): Bryozoan Studies 2004. Proceedings of the 13th International Bryozoology Association Conference, Chile. Balkema Publishing House, London, 49-62.

Ernst, A. \& Rodriguez, S., in press. Stenolaemate bryozoan fauna from the Mississippian of Guadiato area, southwestern Spain.

Golonka, J., 2002. Plate-tectonic maps of the Phanerozoic. [In:] W. Kieslling, E. Flugel, \& J. Golonka (Eds): Phanerozoic reef patterns. Society of Economic Geologists and Mineralogists, Special Publication 72, 21-75.

Golonka, J., 2007. Phanerozoic palaeoenviroment and paleolithofacies maps. Geologia 33, 145-209.

Gorjunova, R.V., 1975. Permskie mshanki Pamira. [Permian Bryozoans of the Pamir]. Trudy Paleontologicheskogo Instituta Academiyi Nauk SSSR 148, 1-125.
Gorjunova, R.V., 1985. Morphologiya, systematika i philogeniya mshanok (Otryad Rhabdomesida). [Morphology, system and phylogeny of Bryozoa (Order Rhabdomesida)]. Trudy Paleontologicheskogo Instituta Akademii Nauk SSSR 208, 1-152.

Gorjunova, R.V., 2006. New bryozoans from the Devonian of Afghanistan and the Carboniferous of Iran. Paleontological Journal 40, 626-635.

Gorjunova, R.V., Markov, A.B. \& Naimark, E.B., 2004. Evolution and biogeography of the Palaeozoic Bryozoa: results of the numerical analysis. GEOS, Moscow, $182 \mathrm{pp}$.

Hall, J., 1886. Bryozoa of the Upper Helderberg groups; plates and explanations. Annual Report of the State Geologist of New York 5, 25-53.

Hammer, Ø., Harper, D.A.T. \& Ryan, P.D., 2001. PAST: paleontological statistics software package for education and data analysis. Palaeontologia Electronica 4(1), 1-9 (http:// palaeo-electronica.org/2001_1/past/issue1_01.htm).

Jaccard, P., 1901. Étude comparative de la distribution florale dans une portion des Alpes et des Jura. Bulletin de la Société Vaudoise des Sciences Naturelles 37, 547-579.

Köhler, W., Schachtel, G. \& Voleske, P., 1996. Biostatistik Einführung in die Biometrie für Biologen und Agrarwissenschaftler. Springer, Berlin, 285 pp.

Morozova, I.P., 1981. Pozdnepaleozoiskie mshanki severo-vostoka SSSR. [Late Palaeozoic Bryozoa from the North-eastern SSSR]. Trudy Paleontologicheskogo Instituta Akademii Nauk SSSR 198, 1-254.

Nekhoroshev, V.P., 1948. Kamennougolnie mshanki severo-vostochnogo Pribalchashjya. [Carboniferous Bryozoa from the northeast Balkhash Lake region]. Akademiya Nauk Kazakhskoi SSR, Alma-Ata, 70 pp.

Nekhoroshev, V.P., 1956. Niznekamennoygolnie mshanki Altaya i Sibiri. [Early Carboniferous Bryozoa of Altai and Siberia]. Trudy VSEGEI (New series) 13, 1-420.

Nikiforova, A.I., 1927. Materialy k poznaniu nizhne-kamennougolnykh mshanok Donetzkogo basseina. [Early Carboniferous Bryozoa of Donetz Basin]. Izwestiya Geologicheskogo Komiteta 46, 246-268.

Nikiforova, A.I., 1933. Karbon Srednei Azii. Materialy k poznaniu mshanok Turkestana. [The Carboniferous of Middle Asia. Materials to the knowledge of bryozoans from Turkestan]. Trudy VSEGEI 207, 1-77.

Nikiforova, A.I., 1948. Niznekamennoygolnie mshanki Karatau. [Early Carboniferous Bryozoa from the Karatau]. Akademiya Nauk Kazakhskoi SSR, Alma-Ata, 53 pp.

Nikiforova, A.I., 1950. Nizhne-kamennougolnye mshanki zapadnoi okonechnosti khr. Talasskogo Alatau. [Early Carboniferous Bryozoa of the western part of the Talassa Alatau Mountain Ridge]. Trudy Instituta Geologii Akademii Nauk Uzbekistan SSR 5, 90-157.

Popeco, L.I., 2000. Karbon Mongolo-Okhotskogo orogennogo poyasa. [The Carboniferous of the Mongolia-Okhotsk orogen belt]. Nauka, Vladivostok, 124 pp.

Ross, J.R.P., 1981. Biogeography of Carboniferous ectoproct Bryozoa. Palaeontology 24, 313-341.

Romantchuk, T.V. \& Kiseleva, A.V., 1968. Novye pozdnepermskie mshanki Dal'nego Vostoka. [New Late Permian bryozoans of the Far East]. Paleontologicheskij Zhurnal 4, 55-60. 
Sakagami, S., 1962. Lower Carboniferous Bryozoa from the Omi limestone, Japan. Part 1. Discovery. Transactions and Processing of the Palaeontological Society of Japan 48, 321-330.

Schulga-Nesterenko, M.I., 1951. Kamennougol'nye fenestellidy Russkoi platfromy. [Carboniferous fenestellids of the Russian Platform]. Trudy Paleontologicheskogo Instituta Akademii Nauk SSSR 32, 1-161.

Simpson, G.B., 1895. A handbook of the genera of the North American Palaeozoic Bryozoa. New York State Geological Survey Annual Reports 14, 403-669.

Stöcklin, J. 1972. Iran central, septentrional et oriental. En collaboration avec les géologues du Service Géologique de l'Iran. Lexique Stratigraphique International 3, 1-376.

Stöcklin, J., Eftekhar-Nezad, J. \& Hushmand-Zadeh, A., 1965. Geology of the Shotori Range (Tabas area, East Iran). Geological Survey of Iran 3, 1-69.

Termier, H. \&Termier, G., 1971. Bryozoaires du Paléozoique supérieur de l'Afghanistan Documentes des Laboratories de Géologie de la Faculté des Sciences de Lyon 47, $1-52$.

Tolokonnikova, Z.A., 2012. Early Carboniferous bryozoans from Western Siberia, Russia.[In:] A. Ernst, P. Schäfer \& J. Scholz (Eds): Bryozoan studies 2010. Lecture Notes in Earth System Sciences, 143, 385-399.

Trizna, V.B., 1958. Rannekamennougolnye mshanki Kuznetzkoi kotloviny. [Early Carboniferous bryozoans of the Kuznetzk depression]. Trudy VNIGRI, Microfauna of the USSR 122, 1-433.

Ulrich, E.O., 1882. American Paleozoic Bryozoa. The Journal of the Cincinnati Society of Natural History 5, 233257.

Ulrich, E.O., 1884. American Paleozoic Bryozoa. The Journal of the Cincinnati Society of Natural History 8, 24-51.

Vine, G.R., 1884. Fourth report of the Committee appointed for the purpose of reporting on fossil Polyzoa. Report of the 53rd Meeting of the British Association for the Advancement of Science, 161-209.

Waagen, W. \& Wentzel, I., 1886. Salt Range fossils. Pt. Coelenterata. Memoir of the Geological Survey of India. Palaeontologica Indica 13, 835-924.
Weddige, K., 1984. Zur Stratigraphie und Paläogeographie des Devons und Karbons von NE-Iran. Senckenbergiana lethaea 65, 179-223.

Wendt, J., Hayer, J. \& Bavandpour, A.K., 1997. Stratigraphy and depositional environment of Devonian sediments in northeast and east-central Iran. Neues Jahrbuch für Geologie und Paläontologie Abhandlungen 206, 277-322.

Wendt, J., Kaufmann, B., Belka, Z., Farsan, N. \& Bavandpour, A.K., 2005. Devonian/Lower Carboniferous stratigraphy, facies patterns and palaeogeography of Iran. Part II. North and central Iran. Acta Geologica Polonica 55, 31-97.

Wyse Jackson, P.N., 1996. Bryozoa from the Lower Carboniferous (Visean) of County Fermanagh, Ireland. Bulletin of The Natural History Museum, London (Geology) 52, 119-171.

Wyse Jackson, P.N., 2006. Bryozoa from Waulsortian buildups and their lateral facies (Mississippian, Carboniferous) in Belgium and Ireland. Courier Forschungsinstitut Senckenberg 257, 149-159.

Wyse Jackson, P.N., McKinney, F. \& Bancroft, A. J., 2006. Fenestrate bryozoa genera based on species from Ireland originally described by Frederick M'coy in 1844. Palaeontology 49, 741-767.

Xia, F.S., 1986. Carboniferous and Early Permian bryozoans from Xainza, Northern Xizang. Bulletin Nanjing Institute of Geology and Palaeontology 10(8), 201-254.

Yazdi, M., 1999. Late-Devonian-Carboniferous conodonts from Eastern Iran. Rivista Italiana di Paleontologica e Stratigrafia 105, 167-200.

Young J., 1883. On Ure's «Millepore», Tabulipora (Cellepora) urei Fleming. Annals and Magazine of Natural History (series 5) 12, 154-158.

Young, J. \& Young, J., 1874. New Carboniferous Polyzoa. Quarterly Journal of the Geological Society 30, 325-335.

Manuscript received 16 June 2013

Revision accepted 12 November 2013 